\title{
The Influence of Vitamin D Receptor Genetic Variants on Bone Mineral Density and Osteoporosis in Chinese Postmenopausal Women
}

\author{
Wei He, ${ }^{1}$ Ming Liu, ${ }^{1}$ Xiaonan Huang, ${ }^{2}$ Zuhong Qing, ${ }^{1}$ and Wei Gao ${ }^{1}$ \\ ${ }^{1}$ Department of Orthopedics, The 305 Hospital of Chinese PLA, Beijing 100017, China \\ ${ }^{2}$ Department of Chemistry, Capital Normal University, Beijing 100037, China \\ Correspondence should be addressed to Ming Liu; mingliu_12@sohu.com
}

Received 13 November 2014; Accepted 20 January 2015

Academic Editor: Marco E. M. Peluso

Copyright (C) 2015 Wei He et al. This is an open access article distributed under the Creative Commons Attribution License, which permits unrestricted use, distribution, and reproduction in any medium, provided the original work is properly cited.

\begin{abstract}
Growing evidence indicates that the vitamin $D$ receptor $(V D R)$ gene is an important candidate gene for influencing the development of osteoporosis. The aim of the study was to evaluate the potential association between genetic variants of VDR gene and bone mineral density (BMD) and osteoporosis in Chinese postmenopausal women. The study included 970 Chinese postmenopausal women at the postmenopausal osteoporosis (482) and healthy controls (488). The BMD of lumbar spine ( $\mathrm{L}_{2-4}$ anterior-posterior view), femoral neck hip, and total hip was evaluated using the Norland XR-46 dual energy X-ray absorptiometry (DEXA). The genotypes of VDR genetic variants were determined by the created restriction site-PCR (CRS-PCR) and confirmed by DNA sequencing methods. Our data indicated that the VDR p.Glicine (Gly)14 alanine (Ala) and p.histidine (His) 305 glutanine (Gln) genetic variants were statistically associated with adjusted femoral neck hip BMD, adjusted lumbar spine BMD, and adjusted total hip BMD ( $P$ values $<0.05)$. Results from this study suggest that the VDR p.Gly14Ala and p.His305Gln genetic variants are significantly associated with BMD decrease in Chinese postmenopausal women and might be used as molecular markers for assessing the risk of BMD and osteoporosis.
\end{abstract}

\section{Introduction}

Osteoporosis, an important and complex health concern in the postmenopausal women, is a polygenic and multifactorial disease that is characterized by the increased risk of fragility fractures and reduced bone mineral density (BMD) [1-11]. In the past decade, many published studies have reported the potential association of environmental and genetic variants with BMD and osteoporosis [8-33]. It is well accepted that the genetic factors play key functions in the pathogenesis of osteoporosis [34-39]. However, the exact etiology of osteoporosis still remains poorly understood. In recent years, the vitamin $\mathrm{D}$ receptor (VDR) gene has been considered as an important candidate gene in the modification and the development of BMD and osteoporosis [8-32]. The VDR gene contained 14 exons and located on chromosome 12q12q14, which is a member of the nuclear receptor family of transcription factors [11, 40, 41]. VDR modulation influences the expression and transcription of genes which involved in bone mass formation and calcium uptake, such as osteocalcin and calcium-binding proteins [11, 42]. The VDR gene is polygenetic gene, and single nucleotide polymorphisms (SNPs) of VDR gene could influence the expression and function of VDR protein, which are proved to influence the risk of BMD and osteoporosis. Morrison et al. firstly investigated that genetic variants in the $V D R$ gene could predict spinal and femoral BMD in Caucasian women $[12,13]$. Since then, a large number of epidemiologic studies have reported the VDR genetic variants (e.g., FokI (rs10735810), BsmI (rs1544410), and ApaI (rs7975232)) are associated with BMD and osteoporosis in different ethnic groups [8-32]. However, to date, there are no published similar studies on the potential relationship of p.Glicine (Gly)14 alanine (Ala) and p.histidine (His) 305 glutanine (Gln) genetic variants in VDR gene with BMD and osteoporosis. Therefore, considering the important role of $V D R$ gene in the pathogenesis of BMD and 
osteoporosis, the objective of this study was to investigate the p.Gly14Ala and p.His305Gln genetic variants of VDR gene and evaluate the potential association of these two SNPs with BMD and osteoporosis in Chinese postmenopausal women.

\section{Subjects and Methods}

2.1. Study Subjects. We enrolled 970 Chinese postmenopausal women containing 482 at the primary postmenopausal osteoporosis (aged 45-86 years) and 488 healthy controls (aged 43-89 years) in this case-control study. All subjects were recruited from the 305 Hospital of Chinese PLA between February 2010 and March 2014. All participants were genetically unrelated Chinese Han ethnic. Subjects with primary postmenopausal osteoporosis were diagnosed and confirmed by doctors. Individuals with a past or present history of diseases known to affect bone metabolism or those who were taking drugs which could affect bone metabolism were excluded from this study. The protocol of this study was approved by the local ethics committee of the 305 Hospital of Chinese PLA. Informed consent was obtained from all subjects enrolled in this case-control study.

2.2. Bone Mineral Density Measurement. The BMD of lumbar spine $\left(\mathrm{L}_{2-4}\right.$ anterior-posterior view), femoral neck hip, and total hip was evaluated using the Norland XR-46 dual energy X-ray absorptiometry (DEXA) (Norland Coopersurgical Corp, WI, USA) [43]. The BMD values were automatically calculated from bone mineral content $(\mathrm{g})$ and bone area $\left(\mathrm{cm}^{2}\right)$ and expressed as $\mathrm{g} / \mathrm{cm}^{2}$. All data are shown as mean $\pm \mathrm{SD}$ (SD, standard definition of the mean, BMD values adjusted by age, height, and weight).

2.3. DNA Extraction and PCR Amplification. Peripheral venous blood was collected from each enrolled subject in this case-control study. Genomic DNA was isolated from blood using the QIAamp DNA Blood Mini Kit (QIAGEN, $\mathrm{GmbH}$, Germany) and then stored at $-80^{\circ} \mathrm{C}$ until analyzed. According to the human VDR gene's DNA sequences (GenBank ID: NG_008731.1) and mRNA sequences (GenBank ID: NM_000376.2), the specific primers of polymerase chain reaction (PCR) were designed using the Primer Premier 5.0 software (Premier Biosoft International, Palo Alto, CA). Table 1 shows the detailed information of the primer sequences, region, annealing temperature, and fragment size. The PCR amplifications for genetic variants of VDR gene were performed in a $20-\mu \mathrm{L}$ reaction mixture, which containing $50 \mathrm{ng}$ template DNA, $1 \mathrm{x}$ buffer $(100 \mathrm{mmol}$ Tris- $\mathrm{HCl}, \mathrm{pH}$ 8.3; $500 \mathrm{mmol} \mathrm{KCl}$ ), $0.25 \mu \mathrm{mol}$ primers, $2.0 \mathrm{mmol} \mathrm{MgCl}_{2}$, $0.25 \mathrm{mmol}$ dNTPs, and 0.5 U Taq DNA polymerase (TaKaRa, Dalian, China). The PCR cycling protocol was carried out by an initial denaturation at $94^{\circ} \mathrm{C}$ for $5 \mathrm{~min}$, followed by 32 cycles of $94^{\circ} \mathrm{C}$ for $30 \mathrm{~s}$, annealing at the corresponding temperature (shown in Table 1 ) for $30 \mathrm{~s}$, and $72^{\circ} \mathrm{C}$ for $30 \mathrm{~s}$, with a final extension at $72^{\circ} \mathrm{C}$ for $10 \mathrm{~min}$. The PCR products were separated on electrophoresis in a $2.0 \%$ agarose gel stained including $0.5 \mu \mathrm{g} / \mathrm{mL}$ ethidium bromide and observed under ultraviolet light.
2.4. Genotyping. The genotypes of genetic variants p.Glyl4Ala and p.His305Gln in VDR gene were determined by the created restriction site PCR (CRS-PCR) method with one of the primers containing a nucleotide mismatch, which enables the use of restriction enzymes for discriminating sequence variations [44-48]. Following manufacturer's instructions, the amplified PCR products $(10 \mu \mathrm{L})$ were digested with $2 \mathrm{U}$ selected restriction enzymes (given in Table 1 ) at $37^{\circ} \mathrm{C}$ for $10 \mathrm{~h}$. The digested PCR products were electrophoresed on a $2.5 \%$ agarose gel containing $0.5 \mu \mathrm{g} / \mathrm{mL}$ ethidium bromide staining for $1 \mathrm{~h}$ at $100 \mathrm{~V}$, and different genotypes of $V D R$ genetic variants were visualized directly under UV light. In order to confirm the concordance of the genotyping results from CRS-PCR method, we selected random samples (20\% of total samples) to be reanalyzed by the DNA sequencing method (ABI3730xl DNA Analyzer, Applied Biosystems, Foster City, CA).

2.5. Statistical Analyses. All statistical analyses were analyzed by the Statistical Package for Social Sciences software (SPSS, version 16.0; SPSS Inc.; Chicago, IL, USA). The chisquared $\left(\chi^{2}\right)$ test was utilized to compare the distributions of allelic and genotypic frequencies in the studied subjects. The genotype frequencies of $V D R$ genetic variants were tested for Hardy-Weinberg equilibrium (HWE). Multiple regression analyses were performed to evaluate the potential relationships between the variables. All data were expressed as mean \pm SD. The significant level was set at $P<0.05$.

\section{Results}

3.1. Identification and Genotyping of VDR Genetic Variants. Through the CRS-PCR and DNA sequencing methods, we detected two VDR genetic variants (p.Gly14Ala and p.His305Gln) in this study. Our DNA sequencing analyses suggest that the p.Gly14Ala is a nonsynonymous mutation, which caused $\mathrm{G} \rightarrow \mathrm{C}$ mutation in exon3 of $V D R$ gene and resulted into Gly to Ala amino acid replacement (p.Gly14Ala, reference sequences, GenBank IDs: NG_008731.1, NM_000376.2, and NP_000367.1). The PCR products were digested with the MaeI restriction enzymes and divided into three genotypes, GG (195 and $18 \mathrm{bp}$ ), GC (213,195 and $18 \mathrm{bp})$, and CC (213 bp, Table 1). As for p.His305Gln, our DNA sequencing analyses indicate that it is also a nonsynonymous mutation, which caused $\mathrm{C} \rightarrow$ $\mathrm{G}$ mutation in exon9 of VDR gene and resulted into His to Gln amino acid replacement (p.His305Gln, reference sequences, GenBank IDs: NG_008731.1, NM_000376.2, and NP_000367.1). The PCR products were digested with the MaeIII restriction enzymes and divided into three genotypes, CC (189 and 17 bp), CG (206,189 and 17 bp), and GG (206 bp, Table 1).

3.2. Allelic and Genotypic Frequencies. The distributions of allelic and genotypic frequencies for p.Gly14Ala and p.His305Gln genetic variants of VDR gene are summarized in Table 2. The allele-G and genotype GG of p.Gly14Ala and allele-C and genotype CC of p.His305Gln genetic variants 


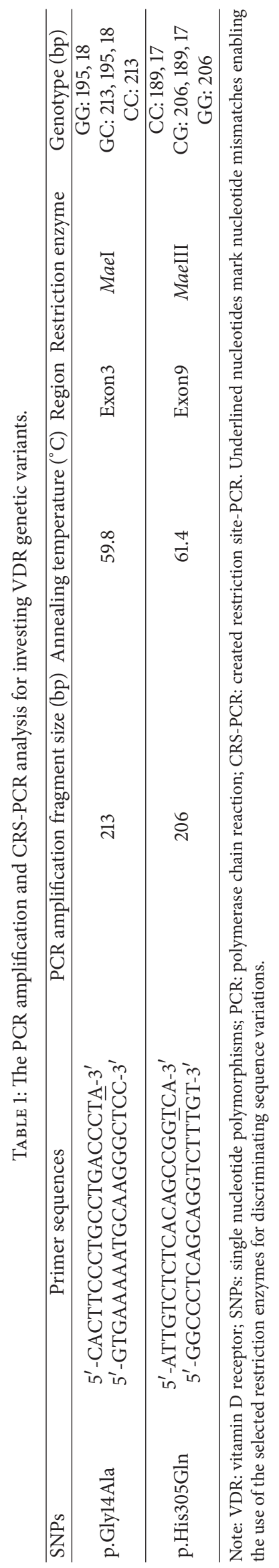




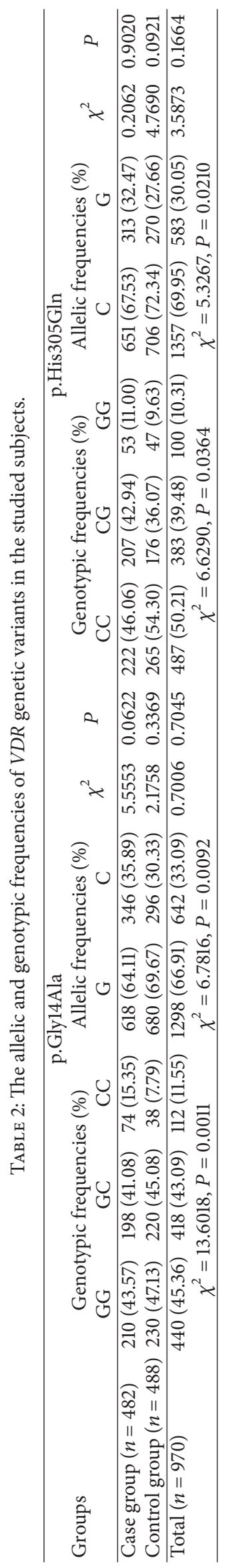


TABLE 3: The characteristics of VDR genetic variants in the studied subjects.

\begin{tabular}{|c|c|c|c|c|c|c|c|c|}
\hline \multirow{2}{*}{$\begin{array}{l}\text { SNPs } \\
\text { Genotype }\end{array}$} & \multicolumn{4}{|c|}{ p.Gly14Ala } & \multicolumn{4}{|c|}{ p.His305Gln } \\
\hline & GG & GC & $\mathrm{CC}$ & $P$ & $\mathrm{CC}$ & CG & GG & $P$ \\
\hline Number (\%) & $440(0.4536)$ & $418(0.4309)$ & $112(0.1155)$ & - & $487(0.5021)$ & $383(0.3948)$ & $100(0.1031)$ & - \\
\hline Age (years) & $62.2 \pm 7.2$ & $62.5 \pm 7.3$ & $62.9 \pm 6.9$ & 0.553 & $61.9 \pm 7.8$ & $62.8 \pm 7.0$ & $62.9 \pm 7.5$ & 0.462 \\
\hline Height $(\mathrm{cm})$ & $161 \pm 7.8$ & $163 \pm 6.8$ & $164 \pm 6.9$ & 0.438 & $158 \pm 7.8$ & $162 \pm 6.2$ & $164 \pm 6.9$ & 0.538 \\
\hline Weight (kg) & $62.4 \pm 6.3$ & $62.6 \pm 6.5$ & $62.8 \pm 6.1$ & 0.329 & $61.9 \pm 7.7$ & $62.7 \pm 6.5$ & $62.9 \pm 6.5$ & 0.365 \\
\hline BMI & $23.2 \pm 3.28$ & $23.4 \pm 3.35$ & $23.7 \pm 3.42$ & 0.452 & $23.3 \pm 3.67$ & $23.6 \pm 3.41$ & $23.7 \pm 3.53$ & 0.239 \\
\hline $\begin{array}{l}\text { Lumbar spine BMD } \\
\left(\mathrm{g} / \mathrm{cm}^{2}\right)\end{array}$ & $0.932 \pm 0.117$ & $0.827 \pm 0.122$ & $0.822 \pm 0.119$ & 0.018 & $0.925 \pm 0.113$ & $0.832 \pm 0.120$ & $0.828 \pm 0.126$ & 0.028 \\
\hline $\begin{array}{l}\text { Femoral neck hip BMD } \\
\left(\mathrm{g} / \mathrm{cm}^{2}\right)\end{array}$ & $0.751 \pm 0.125$ & $0.687 \pm 0.119$ & $0.679 \pm 0.128$ & 0.037 & $0.749 \pm 0.202$ & $0.681 \pm 0.197$ & $0.679 \pm 0.211$ & 0.027 \\
\hline Total hip BMD $\left(\mathrm{g} / \mathrm{cm}^{2}\right)$ & $0.865 \pm 0.134$ & $0.817 \pm 0.156$ & $0.809 \pm 0.129$ & 0.028 & $0.861 \pm 0.129$ & $0.820 \pm 0.219$ & $0.813 \pm 0.172$ & 0.048 \\
\hline
\end{tabular}

Note: VDR: vitamin D receptor; SNPs: single nucleotide polymorphisms; BMD: bone mineral density; BMI: body mass index; Data are shown as mean \pm SD (BMD values adjusted by age, weight, and height).

were predominant alleles and genotypes in the studied subjects, respectively (Table 2). As for p.Gly14Ala, we found significant differences between the allele frequencies of cases ( $G, 64.11 \%$; $C, 35.89 \%$ ) and those of healthy controls $(G$, $69.67 \%$; $\left.\mathrm{C}, 30.33 \%, \chi^{2}=6.7816, P=0.0092\right)$. Besides, the genotypic frequencies in cases (GG, $43.57 \%$, GC, $41.08 \%$, CC, $15.35 \%)$ were statistically significant different from healthy controls (GG, 47.13\%, GC, $45.08 \%$, CC, $7.79 \%, \chi^{2}=13.6018$, $P=0.0011$, Table 2). As for p.His305Gln, significant differences were detected between the allele frequencies of cases (C, 67.53\%; G, 32.47\%) and those of healthy controls (C, $72.34 \%$; G, 27.66\%, $\left.\chi^{2}=5.326, P=0.0210\right)$. Besides, the genotypic frequencies of cases (CC, $46.06 \%$; CG, $42.94 \%$, GG, $11.00 \%)$ were not consistent with those of healthy controls (CC, 54.30\%; CG, 36.07\%, GG, 9.63\%, $\chi^{2}=6.6290, P=$ 0.0364 , Table 3$)$. The chi-squared $\left(\chi^{2}\right)$ test indicates that these two VDR genetic variants were fitted within HWE (all $P$ values $>0.05)$.

3.3. Association between VDR Genetic Variants and Bone Mineral Density. The value of weight, age, height, body mass index (BMI), adjusted femoral neck hip BMD, adjusted lumbar spine BMD, and adjusted total hip BMD in different genotypes in the studied subjects are reported in Table 3. Our data indicated that the VDR p.Gly14Ala genetic variant was statistically associated with adjusted femoral neck hip $\mathrm{BMD}$, adjusted lumbar spine BMD, and adjusted total hip BMD. Individuals with genotype GG showed significantly higher adjusted BMD value than those of genotypes GC and CC ( $P$ values $<0.05$, Table 3$)$. As for p.His305Gln, significant differences within adjusted femoral neck hip $B M D$, adjusted lumbar spine BMD, and adjusted total hip BMD were detected among different genotypes in the studied subjects. Individuals with genotype CC had significantly higher adjusted $\mathrm{BMD}$ value than those of genotypes $\mathrm{CG}$ and GG $(P$ values $<0.05$, Table 3$)$.

\section{Discussion}

It has been confirmed that the osteoporosis is a common skeletal disorder characterized by low bone density caused by decreased bone turnover and increased activity of osteoclasts $[1-9,13,49]$. Growing evidence supports that the VDR gene is one of the most important candidate genes in the modification of BMD metabolism and the pathogenesis of osteoporosis. Genetic variations in the VDR gene have been proved to be potential associated with $\mathrm{BMD}$ and osteoporosis [8-32]. However, results from these published studies were conflicting but not conclusive. The mechanism underlying the association of $V D R$ genetic variations with BMD and osteoporosis still remains uncertain. In the present study, we evaluated the genetic influence of the p.Gly14Ala and p.His305Gln genetic variants of VDR gene with the susceptibility to BMD and osteoporosis in Chinese postmenopausal women. Our data indicate that there are significant differences in the distribution of allelic and genotypic among primary postmenopausal osteoporosis patients and healthy controls for the p.Gly14Ala and p.His305Gln genetic variants of VDR gene ( $P$ values $<0.05$, Table 2$)$, and these two genetic variants were statistically associated with the decreased susceptibility to BMD and osteoporosis ( $P$ values $<$ 0.05 , Table 2 ). Therefore, results from this study suggest that the allele-C and genotype CC of p.Gly14Ala and the allele$\mathrm{G}$ and genotype GG of p.His305Gln genetic variants in VDR gene could contribute to the risk of BMD decrease in Chinese postmenopausal women (Table 3). The VDR p.Gly14Ala and p.His305Gln c.269C $>$ A genetic variants are nonsynonymous coding mutations that caused amino acid replacement in $V D R$ protein. These two genetic variants might be linked to other VDR genetic variants (such as Fok I (rs10735810), BsmI (rs1544410), and ApaI (rs7975232)) which have been proved to affect the function of VDR protein and contribute to influence the development of BMD and osteoporosis. Results from those published reports could support our findings. Our data provide more evidence to support that the VDR genetic variants could influence the development of BMD and osteoporosis. Therefore, we hypothesize that the p.Gly14Ala and p.His305Gln genetic variants of VDR gene play similar functions in the development of BMD and osteoporosis. Our findings indicate that the VDR p.Gly14Ala and p.His305Gln genetic variants were statistically associated with adjusted femoral neck hip BMD, adjusted lumbar spine BMD, and 
adjusted total hip BMD. Results from this study suggest that the VDR p.Gly14Ala and p.His305Gln genetic variants are significantly associated with BMD and osteoporosis in Chinese postmenopausal women and might be used as molecular markers for assessing the risk of osteoporosis.

\section{Conclusions}

In conclusion, this case-control study is first to report the influence of VDR p.Gly14Ala and p.His305Gln genetic variants on BMD and osteoporosis in the Chinese postmenopausal women. Our findings indicate that these two genetic variants may contribute to influence the pathogenesis of BMD and osteoporosis. More epidemiological and mechanistic studies with large different ethnic populations are necessary to confirm our findings and to further evaluate the role of $V D R$ genetic variants in regulating BMD and osteoporosis in the future.

\section{Conflict of Interests}

The authors declare that they have no conflict of interests.

\section{References}

[1] S. R. Cummings, J. L. Kelsey, M. C. Nevitt, and K. J. O’Dowd, "Epidemiology of osteoporosis and osteoporotic fractures," Epidemiologic Reviews, vol. 7, pp. 178-208, 1985.

[2] B. L. Riggs and L. J. Melton III, "Involutional osteoporosis," The New England Journal of Medicine, vol. 314, no. 26, pp. 1676-1686, 1986.

[3] J. A. Kanis, L. J. Melton III, C. Christiansen, C. C. Johnston, and N. Khaltaev, "The diagnosis of osteoporosis," Journal of Bone and Mineral Research, vol. 9, no. 8, pp. 1137-1141, 1994.

[4] L. Geng, Z. Yao, H. Yang, J. Luo, L. Han, and Q. Lu, "Association of CA repeat polymorphism in estrogen receptor beta gene with postmenopausal osteoporosis in Chinese," Journal of Genetics and Genomics, vol. 34, no. 10, pp. 868-876, 2007.

[5] "Consensus development conference: diagnosis, prophylaxis, and treatment of osteoporosis," The American Journal of Medicine, vol. 94, no. 6, pp. 646-650, 1993.

[6] M. T. García-Unzueta, J. A. Riancho, M. T. Zarrabeitia et al., "Association of the 163A/G and 1181G/C osteoprotegerin polymorphism with bone mineral density," Hormone and Metabolic Research, vol. 40, no. 3, pp. 219-224, 2008.

[7] Y. H. Lee, J.-H. Woo, S. J. Choi, J. D. Ji, and G. G. Song, "Associations between osteoprotegerin polymorphisms and bone mineral density: a meta-analysis," Molecular Biology Reports, vol. 37, no. 1, pp. 227-234, 2010.

[8] Y. Li, B. Xi, K. Li, and C. Wang, "Association between vitamin $\mathrm{D}$ receptor gene polymorphismsand bone mineral density in Chinese women," Molecular Biology Reports, vol. 39, no. 5, pp. 5709-5717, 2012.

[9] Z. Mohammadi, F. Fayyazbakhsh, M. Ebrahimi et al., "Association between vitamin D receptor gene polymorphisms (Fok1 and Bsm1) and osteoporosis: a systematic review," Journal of Diabetes \& Metabolic Disorders, vol. 13, article 98, 2014.

[10] R. M. Kanan, “The effect of FokI vitamin D receptor polymorphism on bone mineral density in Jordanian perimenopausal women," Indian Journal of Human Genetics, vol. 19, no. 2, pp. 233-238, 2013.

[11] D. Wang, R. Liu, H. Zhu, D. Zhou, Q. Mei, and G. Xu, "Vitamin $\mathrm{D}$ receptor Fok I polymorphism is associated with low bone mineral density in postmenopausal women: a meta-analysis focused on populations in Asian countries," European Journal of Obstetrics Gynecology and Reproductive Biology, vol. 169, no. 2, pp. 380-386, 2013.

[12] N. A. Morrison, R. Yeoman, P. J. Kelly, and J. A. Eisman, "Contribution of trans-acting factor alleles to normal physiological variability: vitamin D receptor gene polymorphisms and circulating osteocalcin," Proceedings of the National Academy of Sciences of the United States of America, vol. 89, no. 15, pp. 66656669, 1992.

[13] N. A. Morrison, J. C. Qi, A. Tokita et al., "Prediction of bone density from vitamin D receptor alleles," Nature, vol. 367, pp. 284-287, 1994.

[14] Y. Fang, J. B. J. van Meurs, A. D’Alesio et al., "Promoter and 3' untranslated-region haplotypes in the vitamin D receptor gene predispose to osteoporotic fracture: the Rotterdam Study," The American Journal of Human Genetics, vol. 77, no. 5, pp. 807-823, 2005.

[15] O. Kurt, H. Yilmaz-Aydogan, M. Uyar, T. Isbir, M. F. Seyhan, and A. Can, "Evaluation of ERalpha and VDR gene polymorphisms in relation to bone mineral density in Turkish postmenopausal women," Molecular Biology Reports, vol. 39, no. 6, pp. 67236730, 2012.

[16] E. Jakubowska-Pietkiewicz, W. Młynarski, I. Klich, W. Fendler, and D. Chlebna-Sokó1, "Vitamin D receptor gene variability as a factor influencing bone mineral density in pediatric patients," Molecular Biology Reports, vol. 39, no. 5, pp. 6243-6250, 2012.

[17] W. Horst-Sikorska, J. Dytfeld, A. Wawrzyniak et al., "Vitamin D receptor gene polymorphisms, bone mineral density and fractures in postmenopausal women with osteoporosis," Molecular Biology Reports, vol. 40, no. 1, pp. 383-390, 2013.

[18] Y. M. Hussien, A. Shehata, R. A. Karam, S. S. Alzahrani, H. Magdy, and A. M. El-Shafey, "Polymorphism in vitamin D receptor and osteoprotegerin genes in Egyptian rheumatoid arthritis patients with and without osteoporosis," Molecular Biology Reports, vol. 40, no. 5, pp. 3675-3680, 2013.

[19] P. Garnero, O. Borel, E. Sornay-Rendu, and P. D. Delmas, "Vitamin D receptor gene polymorphisms do not predict bone turnover and bone mass in healthy premenopausal women," Journal of Bone and Mineral Research, vol. 10, no. 9, pp. 12831288, 1995.

[20] J. C. Fleet, S. S. Harris, R. J. Wood, and B. Dawson-Hughes, "The BsmI vitamin D receptor restriction fragment length polymorphism (BB) predicts low bone density in premenopausal black and white women," Journal of Bone and Mineral Research, vol. 10, no. 6, pp. 985-990, 1995.

[21] A. Morita, M. Iki, Y. Dohi et al., "Prediction of bone mineral density from vitamin $\mathrm{D}$ receptor polymorphisms is uncertain in representative samples of Japanese Women. The Japanese Population-based Osteoporosis (JPOS) Study," International Journal of Epidemiology, vol. 33, no. 5, pp. 979-988, 2004.

[22] T. R. Eccleshall, P. Garnero, C. Gross, P. D. Delmas, and D. Feldman, "Lack of correlation between start codon polymorphism of the vitamin D receptor gene and bone mineral density in premenopausal french women: the OFELY Study," Journal of Bone and Mineral Research, vol. 13, no. 1, pp. 31-35, 1998.

[23] C. Vandevyver, T. Wylin, J.-J. Cassiman, J. Raus, and P. Geusens, "Influence of the vitamin D receptor gene alleles on bone 
mineral density in postmenopausal and osteoporotic women," Journal of Bone and Mineral Research, vol. 12, no. 2, pp. 241-247, 1997.

[24] G. Qin, Z. Dong, P. Zeng, M. Liu, and X. Liao, "Association of vitamin D receptor BsmI gene polymorphism with risk of osteoporosis: a meta-analysis of 41 studies," Molecular Biology Reports, vol. 40, no. 1, pp. 497-506, 2013.

[25] M. Singh, P. Singh, S. Singh, P. K. Juneja, and T. Kaur, "Vitamin $\mathrm{D}$ receptor (VDR) gene polymorphism influences the risk of osteoporosis in postmenopausal women of Northwest India," Archives of osteoporosis, vol. 8, no. 1-2, p. 147, 2013.

[26] D. Rojano-Mejía, R. M. Coral-Vázquez, A. Coronel et al., "Relation of the estrogen receptor and vitamin $\mathrm{D}$ receptor polymorphisms with bone mineral density in postmenopausal Mexican-mestizo women," Gene, vol. 537, no. 1, pp. 10-14, 2014.

[27] F. Pouresmaeili, J. Jamshidi, E. Azargashb, and S. Samangouee, "Association between vitamin D receptor gene BsmI polymorphism and bone mineral density in a population of 146 Iranian women," Cell Journal, vol. 15, no. 1, pp. 75-82, 2013.

[28] P. Marozik, I. Mosse, V. Alekna et al., "Association between polymorphisms of VDR, COL1A1, and LCT genes and bone mineral density in belarusian women with severe postmenopausal osteoporosis," Medicina (Kaunas), vol. 49, no. 4, pp. 177-184, 2013.

[29] F. Jia, R. F. Sun, Q. H. Li et al., "Vitamin D receptor bsmi polymorphism and osteoporosis risk: a meta-analysis from 26 studies," Genetic Testing and Molecular Biomarkers, vol. 17, no. 1, pp. 30-34, 2013.

[30] A. González-Mercado, J. Y. Sánchez-López, J. A. Regla-Nava et al., "Association analysis of vitamin D receptor gene polymorphisms and bone mineral density in postmenopausal MexicanMestizo women," Genetics and Molecular Research, vol. 12, no. 3, pp. 2755-2763, 2013.

[31] A. Casado-Díaz, R. Cuenca-Acevedo, C. Navarro-Valverde et al., "Vitamin D status and the Cdx-2 polymorphism of the vitamin $D$ receptor gene are determining factors of bone mineral density in young healthy postmenopausal women," Journal of Steroid Biochemistry and Molecular Biology, vol. 136, no. 1, pp. 187-189, 2013.

[32] T. Canto-Cetina, J. A. Cetina Manzanilla, L. González Herrera et al., "VDR polymorphisms are associated with bone mineral density in post-menopausal Mayan-Mestizo women," Annals of Human Biology, 2014.

[33] H. Ohmori, Y. Makita, M. Funamizu et al., "Linkage and association analyses of the osteoprotegerin gene locus with human osteoporosis," Journal of Human Genetics, vol. 47, no. 8, pp. 400-406, 2002.

[34] O. M. E. Albagha and S. H. Ralston, "Genetics and osteoporosis," Rheumatic Disease Clinics of North America, vol. 32, no. 4, pp. 659-680, 2006.

[35] T. Hosoi, "Genetic aspects of osteoporosis," Journal of Bone and Mineral Metabolism, vol. 28, no. 6, pp. 601-607, 2010.

[36] S. H. Ralston, "Genetics of osteoporosis," Annals of the New York Academy of Sciences, vol. 1192, pp. 181-189, 2010.

[37] S. Ferrari, "Human genetics of osteoporosis," Best Practice \& Research Clinical Endocrinology \& Metabolism, vol. 22, pp. 723735, 2008.

[38] C.-L. Cheung, S.-M. Xiao, and A. W. C. Kung, "Genetic epidemiology of age-related osteoporosis and its clinical applications," Nature Reviews Rheumatology, vol. 6, no. 9, pp. 507-517, 2010.
[39] H. Y. Zhao, J. M. Liu, G. Ning et al., "The influence of Lys3Asn polymorphism in the osteoprotegerin gene on bone mineral density in Chinese postmenopausal women," Osteoporosis International, vol. 16, no. 12, pp. 1519-1524, 2005.

[40] J. M. Zmuda, J. A. Cauley, and R. E. Ferrell, "Molecular epidemiology of vitamin D receptor gene variants," Epidemiologic Reviews, vol. 22, no. 2, pp. 203-217, 2000.

[41] D. D. Moore, S. Kato, W. Xie et al., "International union of pharmacology. LXII. The NR1H and NR1I receptors: Constitutive androstane receptor, pregnene $\mathrm{X}$ receptor, farnesoid $\mathrm{X}$ receptor $\alpha$, farnesoid X receptor $\beta$, liver X receptor $\alpha$, liver X receptor $\beta$, and vitamin D receptor," Pharmacological Reviews, vol. 58, no. 4, pp. 742-759, 2006.

[42] S. Ferrari, J.-P. Bonjour, and R. Rizzoli, "The vitamin D receptor gene and calcium metabolism," Trends in Endocrinology and Metabolism, vol. 9, no. 7, pp. 259-265, 1998.

[43] P. Tothill, M. A. Laskey, C. I. Orphanidou, and M. van Wijk, "Anomalies in dual energy X-ray absorptiometry measurements of total-body bone mineral during weight change using Lunar, Hologic and Norland instruments," British Journal of Radiology, vol. 72, pp. 661-669, 1999.

[44] A. Haliassos, J. C. Chomel, L. Tesson et al., "Modification of enzymatically amplified DNA for the detection of point mutations," Nucleic Acids Research, vol. 17, no. 9, article 3606, 1989.

[45] Z. Yuan, J. Li, X. Gao, and S. Xu, "SNPs identification and its correlation analysis with milk somatic cell score in bovine MBL1 gene," Molecular Biology Reports, vol. 40, no. 1, pp. 7-12, 2013.

[46] Z. Yuan, J. Li, J. Li et al., "Investigation on BRCA1 SNPs and its effects on mastitis in Chinese commercial cattle," Gene, vol. 505, no. 1, pp. 190-194, 2012.

[47] Z. Yuan, J. Li, X. Gao, H. Gao, and S. Xu, "Effects of DGAT1 gene on meat and carcass fatness quality in Chinese commercial cattle," Molecular Biology Reports, vol. 40, no. 2, pp. 1947-1954, 2013.

[48] C. J. Zhao, N. Li, and X. M. Deng, "The establishment of method for identifying SNP genotype by CRS-PCR," Yi chuan= Hereditas / Zhongguo yi chuan xue hui bian ji, vol. 25, pp. 327329, 2003.

[49] R. S. Weinstein, R. L. Jilka, A. Michael Parfitt, and S. C. Manolagas, "Inhibition of osteoblastogenesis and promotion of apoptosis of osteoblasts end osteocytes by glucocorticoids potential mechanisms of their deleterious effects on bone," Journal of Clinical Investigation, vol. 102, no. 2, pp. 274-282, 1998. 


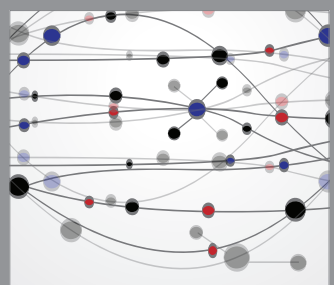

The Scientific World Journal
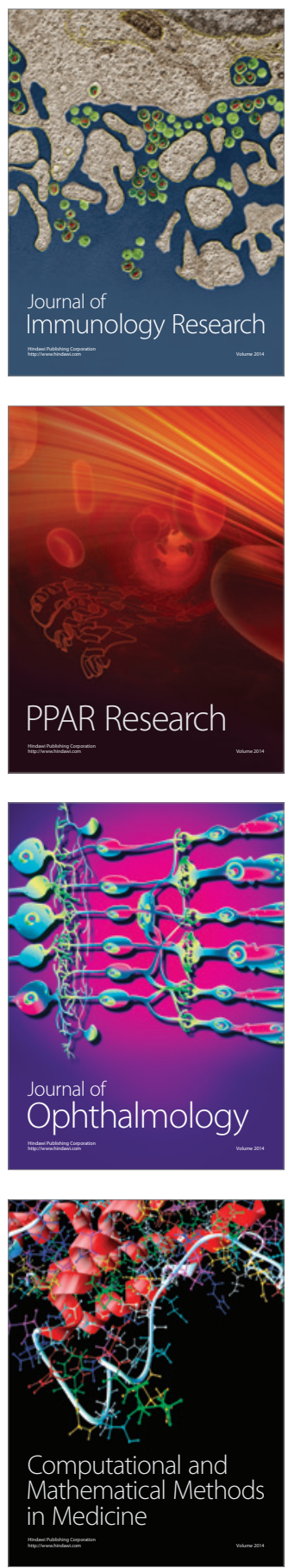

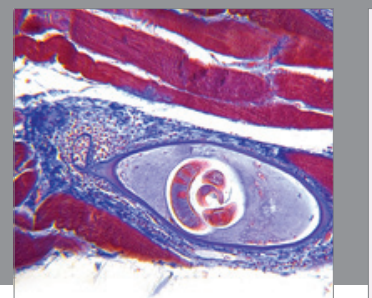

Gastroenterology

Research and Practice
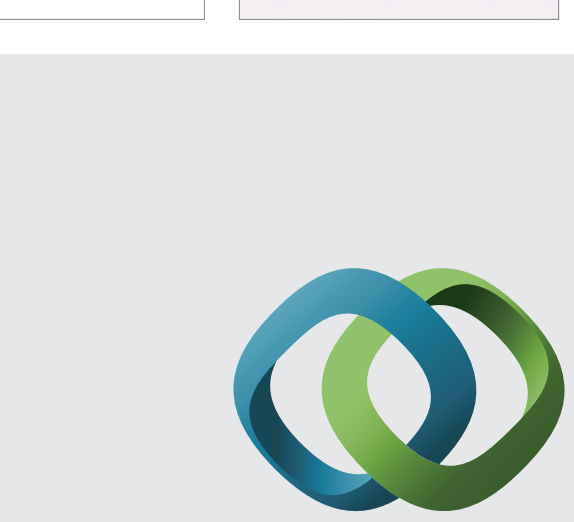

\section{Hindawi}

Submit your manuscripts at

http://www.hindawi.com
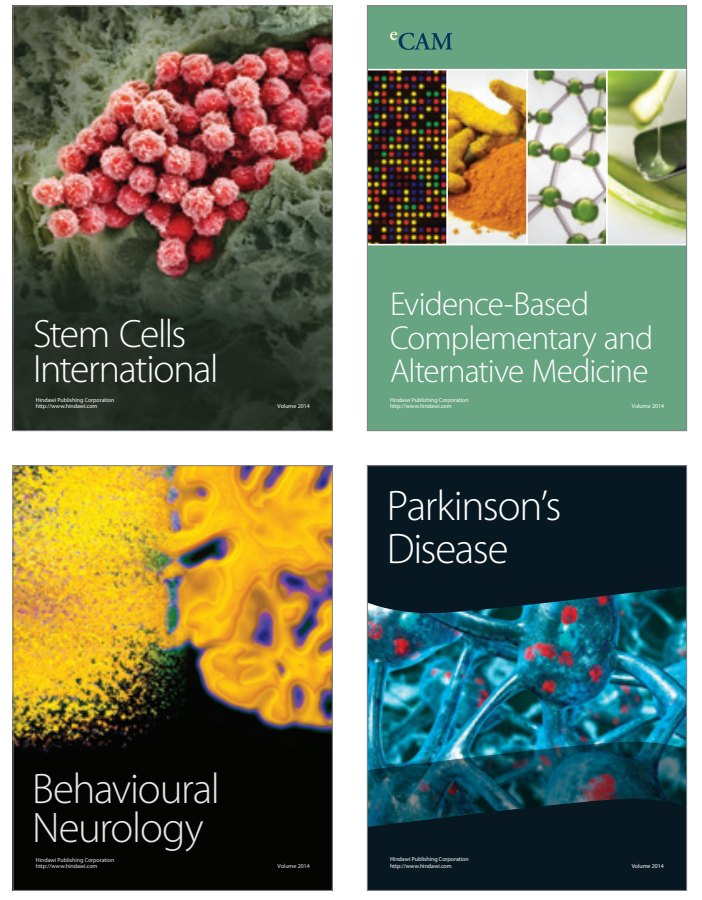
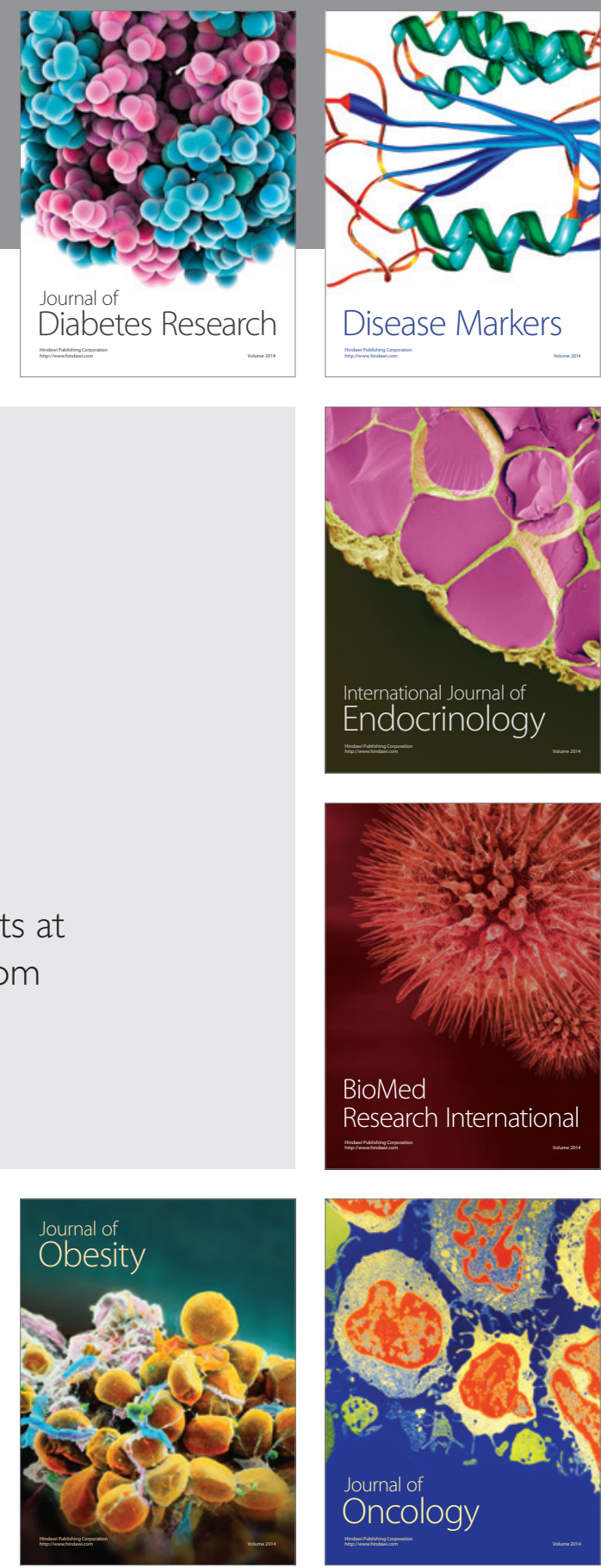

Disease Markers
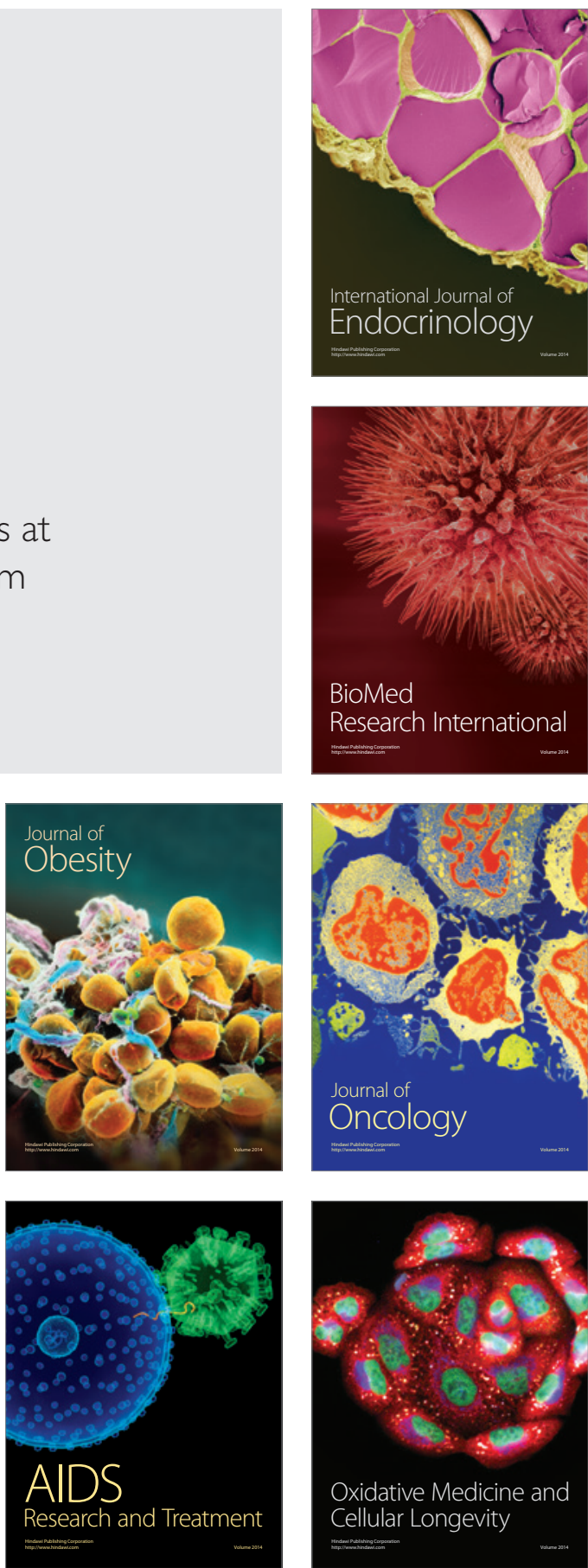